\title{
Socio-Economic Implications of Recurrent Flooding on Women Development in Southern Ijaw Local Government Area, Bayelsa State, Niger Delta Area of Nigeria
}

\author{
Oluyemi Ayorinde Akintoye1, Abiodun Komomo Eyong2, Devine Offiong Effiong1, \\ Peter Okpe Agada ${ }^{3}$, Opaminola Nicholas Digha ${ }^{1}$ \\ ${ }^{1}$ Department of Geography and Environmental Science, University of Calabar, Calabar, Nigeria \\ ${ }^{2}$ Department of Public Health, University of Calabar, Calabar, Nigeria \\ ${ }^{3}$ Department of Pharmacy, University of Calabar Teaching Hospital, Calabar, Nigeria \\ Email: oluyemi.akintoye@unical.edu.ng,komomoeyong@yahoo.com,pagada09@gmail.com, \\ dighaopaminola@yahoo.com
}

Received 16 May 2016; accepted 6 August 2016; published 10 August 2016

Copyright (C) 2016 by authors and Scientific Research Publishing Inc.

This work is licensed under the Creative Commons Attribution International License (CC BY).

http://creativecommons.org/licenses/by/4.0/

(c) (i) Open Access

\section{Abstract}

The main purpose of this study is to identify the socio-economic implications of re-current flooding on women development in southern Ijaw Local Government Area. Generally, flooding may result in socio-economic, ecological and health problems. This study assumes that on flood days the movement of customers and sellers tends to be hindered, thus resulting in the retardation of transactions and the reduction of daily income earned. The study compared the situation of female traders with that of male traders. Both primary and secondary data were used in this study. Primary data were collected using an open-ended questionnaire. A total of 83 questionnaires were randomly distributed to members of four communities, which were selected through stratified random sampling procedures. Also 33 randomly selected women and men respectively, engaged in marketing activities from open and locked-up shops, were sampled to observe the level of their personal income (in Naira), from customers patronage during 3 flood days and 3 non-flood days. Other data and information were obtained through Key Informants Interview (KII), and observations. Hypotheses I and II were tested using Analysis of Variance (ANOVA) statistical model. Null hypothesis $\mathrm{I}\left(\mathrm{H}_{0}\right)$, which states that "There is no statistically significant difference in the income earned by men and women traders from marketing activities on flood days and non-flood days in Southern Ijaw Local Government Area, Bayelsa State", is accepted (F-value: 3.8723939, P-value: 2.494E-05), whereas null hypothesis II $\left(\mathrm{H}_{0}\right)$, which states that "There is no statistically significant difference in the income earned by women traders from marketing activities on flood and non-flood days in Southern Ijaw Local Government Area, Bayelsa State, is rejected (F-value: 2.524902, P-value: 0.030069). Thus while there is no significant difference in the earnings of male 
and female traders on flood and non-flood days, there are significant differences in sales earning among women traders on those days. Factors affecting trading income on flood and non-flood days include accessibility to business premises by customers, ability of male marketers to afford noneasily flooded business premises; and women traders with limited resources often have less suitably drained premises. Reduced total household income can detrimentally affect food affordability, availability, household nutrition, family health and wellbeing. Recommendations highlighting the roles of communities, government and stakeholders in flood management are proffered.

\section{Keywords}

\section{Recurrent Flooding, Women Development, Socio-Economic Activities, Niger Delta Area}

\section{Introduction}

Flood is defined in a variety of ways, according to type, origin and magnitude. Generally, it is an unusual high stage of water in a stream channel [1] or the stage at and above which the stream channels become filled and overflow its banks. When it causes damage to goods and properties or impairs human activities, flood becomes a hazard [2]. According to [3], a flood can be defined as a natural phenomenon that results in the temporary submerging with water of a land that does not occur under normal conditions. [4] also pointed out that flooding was a general temporary condition of partial or complete inundation of normally dry area from overflow of inland or tidal waters from unusual and rapid accumulation or run-off.

The analysis of socio-economic components of flooding adopts long-term risk management strategies grounded in an understanding of exposure to the flood, hazard characteristics and pattern of vulnerability and the relationship between different stakeholders in the perception of food risk [5]. Since flood is often naturally occurring, they cannot be prevented and have the potential to lead to fatal causes such as displacement of people and damage to the environment [6].

Floods, although a natural disaster, could also be caused by anthropogenic activities and human interventions in natural processes, such as increase in settlement areas, population growth located in areas prone to flooding [7]. The effects of natural hazards, such as floods, can be felt at local levels, affecting communities and neighborhoods, or at regional or national levels, affecting an entire drainage basin and large spheres of land between states [8]. African nations have also been badly affected by floods. Media and aid organizations have reported a lot of flooding incidences in sub-Saharan Africa, which resulted from several days of rainfall [9]. The cost of losses resulting from floods in African countries like Mozambique has been in the order of millions of United States Dollars (USD) and the country has been affected by flooding almost yearly since it gained its independence from Portugal in 1975 [10].

[11] has indicated that natural disasters disorder the existing everyday normative practices. He pointed out that the magnitude of any disaster created risk and vulnerability in different ways that applied to different groups. Also he stated that the consequences of material and non-material risk and vulnerability downgraded the existing social structure and social order of the society, which reflected in the process of the cultural system, demographic scenario, social process, socialization, good governance and women empowerment. He adopted the concept "chronic poverty" as a condition created by intergenerational socio-economic and cultural processes. His analysis encompassed the interrelationship and interdependency between unequal access to resources and recovery process on the context of disaster vulnerability, which could otherwise create persistent poverty.

According to [12], different social groups have different needs when a disaster occurs, generally the marginalized group usually has less social power, fewer economic resources and physical capacity to anticipate, survive and recover from the effects of the disaster. [13] has pointed out that floods are in different forms, while [14] and [6] have also mentioned that these forms of floods spread across various regions. They include river floods, coastal floods, urban floods, and flash floods. In the opinion of [15] the causes of floods can be broadly divided into the physical aspects, such as climatological forces, as well as human influences such as vegetation, and urban development. He indicated that the most common causes of floods were climate related, most notably rainfall.

[16] has examined the impact of floods on the socio-economic livelihoods of people in Sikaunzwe Community in Kazungula District of Zambia. He pointed out that [17] had stated that the frequency of natural disasters 
had been increasing over the years, resulting in loss of life, damage to property and destruction of the environment. The number of people at risk has been growing each year and the majority is in developing countries with high poverty levels making them more vulnerable to disasters. [16] also made us to know that [18] had explained that due to high poverty levels, people had become more vulnerable because they lived in hazardous areas including flood plains and steep hills. They have fewer resources which make them more susceptible to disasters. Also they are less likely to receive timely warnings. Furthermore, even if warnings are issued, they have fewer options for reducing losses in a timely manner. The poverty level affects the resilience and process of recovery from disasters. Disaster mitigation, preparedness and prevention needs to address socio-economic issues not only geological and meteorological aspects.

[15] has also indicated that a flood event is not considered to be a natural hazard unless it's observed to be a threat to human life and/or property. Low-lying parts of flood plans, low-lying coasts and deltas, small basins subject to flash floods, are usually easily flooded. Rivers offer human populations transport links, while it's a valuable source of domestic water and provides natural recreational amenities. Notably, fertile plains are also attractive places for settlements. Floods then become a major natural hazard because of the high human population densities that inhabit these lands.

[19] has informed that studies have revealed that the economic impact of natural disasters portray a marked upward trend over the last several decades. The consequences of hazards on communities in developing countries especially the least developed countries, has been in increasing their vulnerability and setting back their economic as well as social growth, sometimes by decades. In the past floods have resulted in human deaths, destruction of social and economic infrastructure, as well as the degradation of already fragile ecosystems. Social impacts tend to include changes in the life and activities of people, and their culture, community, political systems, environment, health and wellbeing. Other areas of impact include their personal and property rights and their fears and aspirations. [20] observed that social impacts can cause significant problems for the long term functioning of specific types of households and businesses in an affected community, while [21] pointed out that some groups are more likely to be impacted by floods than others. For instance vulnerability is not enhanced by poverty level, although the poor are most vulnerable because of the lack of options available to them. Poverty and development process have been associated with vulnerability to disaster. Also people's class, ethnicity, gender, disability and age are among identified factors which determine vulnerability of human population.

[21] continued by stating that despite the observation that women are more vulnerable to disasters than men, due to conventional gender responsibilities and relations, they are not usually as helpless as generally assumed. It is noteworthy to consider that women have valuable knowledge and experience in coping with disasters. They observed that such strengths and capabilities of women are often unconsidered in policy decisions and in mitigation strategies. By overlooking these endowments, dependency situations are erroneously evolved. Poor knowledge of gender differences has often resulted to insensitive and ineffective relief operations, which does not significantly consider women's needs and their abilities to contribute to mitigation and relief work.

In another light [22] explained that efforts aimed at reducing poverty is one of the great challenges encountered in the world presently. [23] wrote that women and children are the most affected by flood events and disasters. [24] expatiated that extreme events affect both the formal and informal economics. This results in bottlenecks in assessing flood impacts, which could be direct and indirect in nature. Tangible form of damage resulting from floods may include structural damage to homes, shops and public buildings and their contents and loss of crops and livestock. [24] gave further insights on these issues, arguing that floods often result in major infrastructure damage, which usually include damage to roads, railway lines, airports, electricity supply systems, water supply and sewage disposal systems, the consequences of flood events on movement disruption and transportation systems for goods and costumers at the various markets and effect on transaction in the study area of this study will be of great interest. Notably, [24] concluded that the economic effects of flooding are often much greater than the flood itself.

Strategies for mitigating against flood risks, include amongst others; development of Flood Early Warning System (FEWS) [25] and Structural and Non-structural Mitigation [26]. The incidents of flooding have claimed many lives, rendered many others homeless and disrupted a wide-range of environmental factors and socio-economic activities related to agriculture, vegetation and sustenance of human beings and wild life [3]-[13]. Coupled with the environmental problems associated with petroleum resources exploration and exploitation which has characterized the Niger Delta Area, the issues of flooding requires rapid management strategies. [27] for instance has emphasized the deep rooted problems of crude oil Exploration and spillage in the Niger Delta of Nigeria. This could also be complicated by flooding. 
Nigeria has had its own fair share of flooding and has recorded some of the highest death tolls in the West African Region. In the northern parts of the country, entire villages and huge spaces of agricultural land have been destroyed by flooding [28]. Flooding in urban areas is seriously becoming an ecological menace in Nigeria as several coastal areas along the Atlantic Ocean, surrounding cities and river valleys are affected by flooding on a yearly basis [4]. Floods have caused land degradation in some parts of the country [29]. There are obvious reasons for flooding, especially in municipalities and coastal areas in Nigeria [30].

Notably, Odubo (2014) has carried out a study of the socio-cultural effects of flooding in Southern Ijaw, Bayelsa State, Nigeria. He noted that in Nigeria, flood has been documented to have affected and displaced more people than any other disaster [31]. Flood has not only been pointed out to have caused large scale damage to properties, it is also claimed that flood disasters perilously affect large and diverse human populations, communities and institutions. According to him Nigeria, particularly, the Niger Delta area was affected by flooding, which resulted in the displacement of large populations of residents from their socio-cultural and economic heritage. Although Bayelsa State was identified as one of the most affected, the situation observed in Southern Ijaw Local Government Area was most devastating. The study observed that the socio-economic effects of the flood include displacement of communities, rendering of families homeless, disruption of business activities and vulnerability to various forms of crimes.

Since the effect of flooding on movement and invariably the ease of doing trading business at various market locations, based on gender differences, as well as its socio-economic implication on household income is the main interest of this study, there is a considerably departure from the widespread issues examined by Odubo (2014). Consequently, the problem which this present study examines is the socio-economic implication of re-current flooding on the income of female traders in southern Ijaw Local Government Area, Bayelsa State. This study of female traders' income is juxtaposed against that of the income earned by male traders for meaningful comparative analyses.

The impact of such intense flooding patterns and processes in an environment noted for frequent crude oil exploitation operational accidents, as well as induced crude oil spillages due to vandalization and sabotage activities, and widespread local crude oil refining could be more devastating on the marine environment, especially in such a vulnerable ecological area.

\subsection{Aim and Objectives}

The aim of this study is to examine the implication of recurrent flooding on women development in Southern Ijaw Local Government Area, in the heart of the Niger Delta Area of Nigeria. The study is aimed at comparing the level of vulnerability of male and female traders during flood and non-flood days, with major emphasis on incomes from trading transactions. Thus this study specifically focuses on the socio-economic implication of flood events on trading activities viewed from a gender perspective. A knowledge of this will help in gaining an integrated perception in comparing the possibly existing gap between the socio-economic growth of male and female traders and consider how this type of occurrences, if negative, poses a threat to the development of women in this region. Consequently, the objectives of the study are to: 1) identify the causes of re-current flooding in southern Ijaw L.G.A, Bayelsa State; 2) assess the comparative effect of flooding on the income of male and female marketers in the study area; 3 ) identify the more vulnerable gender group to consequences of flood events on personal income 4 make relevant suggestions on how to prevent and control future occurrences.

Thus, for this study it could be assumed that during flood days the movement of traders and buyers from house to business premises is hindered. However, a transect walk through business premises shows that there seems to be a pattern, where male traders could afford non-easily flooded business premises, while women traders, who tend to have limited trading resources, usually rent or acquire premises which are less developed infrastructural, more likely to be flooded and as such less accessible, within the same area.

There is also the usual concentration of traders selling the same products in a particular area. Most often accessibility to the area may be almost uniform. There may be gender sensitivity in types of items sold, in some areas of the market, while in some areas it is not. Sometimes both a man and his wife may co-own a trading outlet. A comparative study of both female and male respondents will also assist in determining if women are more affected by flood events, through increase or decrease in patronage.

\subsection{Hypothesis Formulation}

In this study the following null $\left(\mathrm{H}_{\mathrm{o}}\right)$ hypotheses were tested:- 
Hypothesis I: $\mathrm{H}_{0}$ : "There is no statistically significant difference in the income earned by men and women traders from marketing activities on flood days and non-flood days in Southern Ijaw Local Government Area, Bayelsa State".

Hypothesis II: $\mathrm{H}_{0}:$ "There is no statistically significant difference in the income earned by women traders from marketing activities on flood and non-flood days in Southern Ijaw Local Government Area, Bayelsa State”.

\subsection{Study Area}

The study area is Southern Ijaw Local Government Area of Bayelsa State. Its headquarters is in the town of Oporoma. It is located on Latitude $44^{\circ} 48^{\prime} 17^{\prime \prime} \mathrm{N}$ and Longitude $6^{\circ} 04^{\prime \prime} \mathrm{E}$. The area has a coastline of approximately $60 \mathrm{~km}$ on the Bight of Benin. It is the largest local government in Nigeria. The people and their language are known as Izon.

Southern Ijaw has a land area of $2682 \mathrm{~km}^{2}$ approximated and a population of 319,413 persons (NPC Census, 2006) [32]. Southern Ijaw L.G.A has a riverine and estuarine setting. A lot of her communities are often completely surrounded by water, hence making these communities inaccessible by road. Figure 1 presents a map of Bayelsa State of Nigeria, showing Southern Ijaw Local Government Area, which is the study area.

\subsubsection{Physiographic Characteristics}

The study area lies in the heaviest rainfall area in Nigeria with heavy rainfall almost all year round and a short dry season. The area's climate supports the cultivation of oil palm, cocoa rice, banana, yam, cocoyam, coconut, cassava, sugarcane etc. The amount of rainfall is adequate for a year round crop production. The vegetation of Southern Ijaw is composed of ecological zones which include coastal barrier Island forests, mangrove forest, and fresh water swamp. The difference with various soil units in the area and they constitute part of the eco-systems.

\subsubsection{Socio-Economic Activities}

The socio-economic activities of the people in Southern Ijaw may be considered under three main headings namely, primary occupations, secondary occupations and tertiary occupations. The major traditional primary

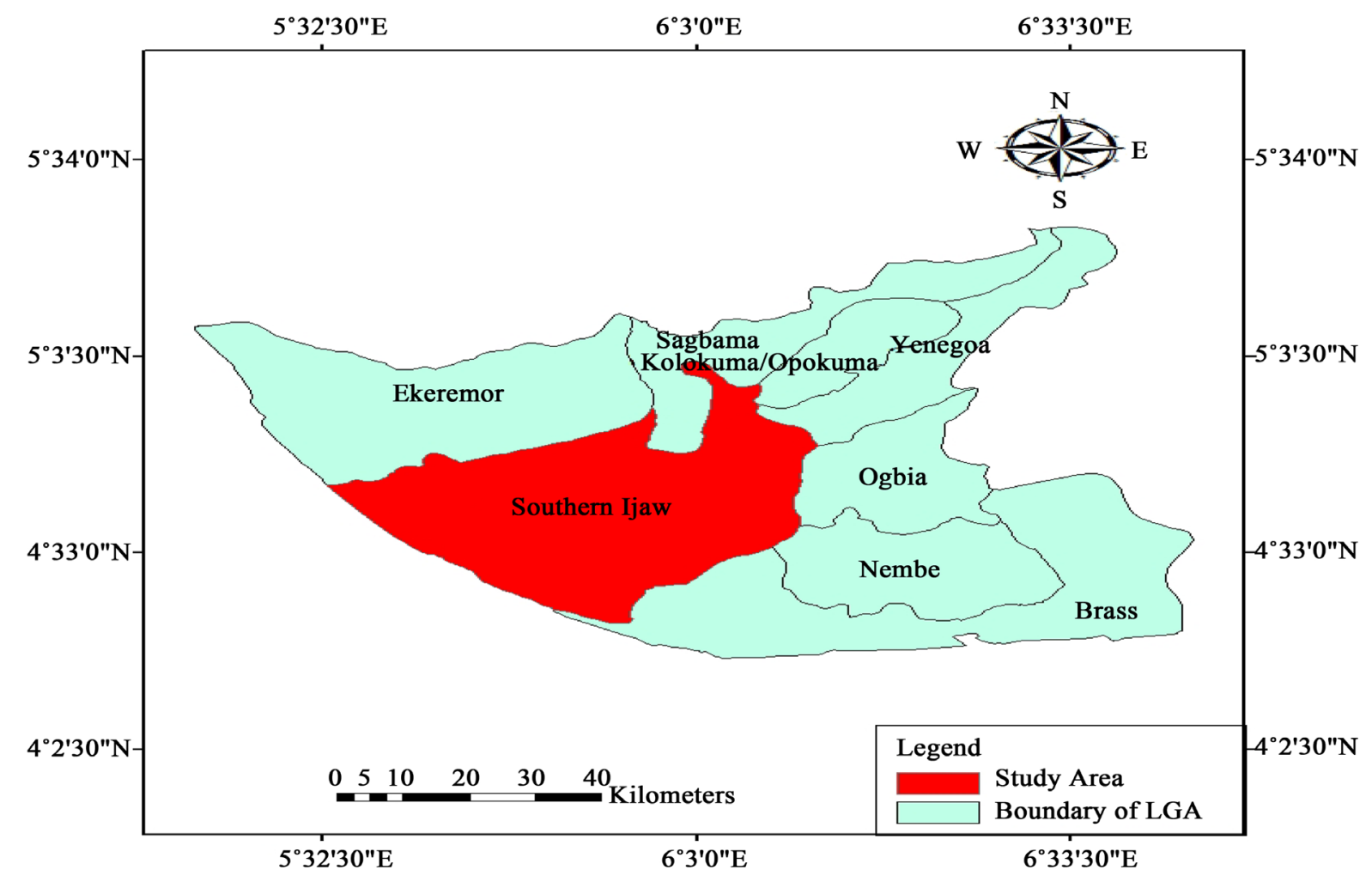

Figure 1. Map of Bayelsa state of Nigeria showing southern Ijaw local government area (study area). 
occupations include fishing, commerce and water transportation. However, crude oil exportation by multinational companies and the local crude oil refining, have since become the major sources of socio-economic activities in the area. The area also has higher educational institutions like the Niger Delta University (NDU) in Amassoma and Federal Polytechnic Ekowe, amongst others.

\section{Method of Study}

This section contains the method of study adopted for this research. The presentation is sub-divided into types of data, sampling population, and data collection methods and data analysis techniques.

\subsection{Types of Data}

Data types obtained by the researcher during this study were generated from two (2) sources, which include primary and secondary data. Both of these were relevant to the assessment of the implications of flooding on the socio-economic activities of female (and male) traders in southern Ijaw, Bayelsa State.

\subsection{Primary Data}

The primary data obtained include data on causes of re-current flooding in the study area, the level of the effect of flooding on the income of male and female traders in the area, identification of the most vulnerable groups to flooding,

1) Questionnaire: Items on the distributed questionnaire was arranged in an orderly form that helped the researchers to obtain relevant data and information aimed at achieving the study objectives. Questionnaire copies were largely distributed to household heads in order to collect unrepeated data.

The questionnaire was an open-ended questionnaire, and it was divided into two sections. Sections A contains questions on the respondent's personal data, while section B contains items meant to obtain data relevant to stipulated research objectives.

2) Oral interviews: These interviews were conducted in form of Focus Group Discussions (FGDs) and Key Informant Interviews (KII) with groups of key informants, household heads, farmers, traders, fishermen and women and so on.

3) Direct observation: Here, the researchers' observations were carried out through visual assessment of field objects, people, facilities and processes. Observations were carried out on markets and trading activities, non-flood days, movement of buyers on rainy and non-rainy days, flood situations, transportation activities and other relevant processes. Observed are also flooded farmlands, houses/compounds, schools and roads affected by flooding.

\subsection{Sample Population of Study}

The sample population consisted of 4952 persons. The estimated number of households is 868. Only four (4) communities within the sample population of communities were selected for several reasons which include low research budget, the wide expanse of the area and time. Also not all the members of the population were engaged in trading. Thus thirty-one (31) males and thirty-one (31) female traders, with trading outlets within Obololi, Emete, Lobia and Azama communities were purposively selected, due to their engagement in trading activities and willingness to participate in the study. These latter selected respondents were monitored for the actual amount of total sales on three (3) flood days, and three (3) non-flood days, (in this case beginning from the day after flood and invariably rainfall had ceased). Table 1: shows the nominally arranged list of villages in the study area. This served as the sample population for the study. Table 2 presents the sample framework for the study.

\subsection{Sampling Techniques}

Stratified random sampling and simple random sampling techniques were adopted in this study. Firstly selection of 4 communities was done, followed by simple random sampling which was employed in selecting 83 respondents/household heads to which the questionnaires were administered. A total of 80 questionnaires were retrieved. However only 75 questionnaires were properly filled and thus used in data analyses. Also Table 2 
Table 1. Communities in southern Ijaw local government area.

\begin{tabular}{|c|c|c|c|}
\hline $\mathrm{S} / \mathbf{N}$ & Villages & $\mathrm{S} / \mathrm{N}$ & Villages \\
\hline 1 & Abagbene & 33 & Ekowe \\
\hline 2 & Agidigbene & 34 & Emete \\
\hline 3 & Agoubin & 35 & Eniwari \\
\hline 4 & Amassana & 36 & Ezetu \\
\hline 5 & Amatoro & 37 & Ekeni \\
\hline 6 & Angiama & 38 & Eniwari \\
\hline 7 & Apoi & 39 & Ezetu \\
\hline 8 & Ayama & 40 & Fonibri \\
\hline 9 & Ayougbene & 41 & Furupah \\
\hline 10 & Azuzuamma & 42 & Gabaran \\
\hline 11 & Baberegbene & 43 & Idirigbene \\
\hline 12 & Diebu & 44 & Igbomotoru \\
\hline 13 & Ikeingbenbiri & 45 & Igboibiri \\
\hline 14 & Kainyanbiri & 46 & Ikebiri \\
\hline 15 & Kemiegbene & 47 & Ikeinbiri \\
\hline 16 & Kolokologbene & 48 & Ikoromogbene \\
\hline 17 & Korokorosei & 49 & Kassama \\
\hline 18 & Lobia & 50 & Kemebiama \\
\hline 19 & Nangebene & 51 & Koluama \\
\hline 20 & Ofonigbene & 52 & Lasukogbene \\
\hline 21 & Olugboiri & 53 & Luduan \\
\hline 22 & Omomobiri & 54 & Obololi \\
\hline 23 & Onyema & 55 & Okpotuwari \\
\hline 24 & Opuama & 56 & Olugbobro \\
\hline 25 & Owelkorogha & 57 & Ondewari \\
\hline 26 & Peremabiri & 58 & Oporoma \\
\hline 27 & Sampou & 59 & Otuan \\
\hline 28 & Togogbene & 60 & Oyereghene \\
\hline 29 & Ukparatibu & 61 & Poloubou \\
\hline 30 & Umbugbene & 62 & Ukubie \\
\hline 31 & Tebidada & 63 & Torubobougbene \\
\hline 32 & Ekeni & & \\
\hline
\end{tabular}

Table 2. Sample framework for the study.

\begin{tabular}{|c|c|c|c|c|c|c|c|c|}
\hline $\mathbf{S} / \mathbf{N}$ & $\begin{array}{l}\text { Names of } \\
\text { Sample } \\
\text { Villages }\end{array}$ & $\begin{array}{c}\text { Estimated } \\
\text { Study } \\
\text { Population }\end{array}$ & $\begin{array}{l}\text { Estimated } \\
\text { Average } \\
\text { House-Hold } \\
\text { Size }\end{array}$ & $\begin{array}{l}\text { Estimated } \\
\text { House-Hold } \\
\text { Number }\end{array}$ & $\begin{array}{c}\text { \% of } \\
\text { Sampled } \\
\text { House-Hold }\end{array}$ & $\begin{array}{c}\text { No. of } \\
\text { Sampled } \\
\text { Households }\end{array}$ & $\begin{array}{c}\text { No. of } \\
\text { Retrieved } \\
\text { Questionnaires } \\
\text { Properly } \\
\text { Filled }\end{array}$ & $\begin{array}{c}\text { \% of } \\
\text { Returned } \\
\text { Questionnaire }\end{array}$ \\
\hline 1 & Obololi & 1577 & 7 & 225 & 10 & 23 & 22 & 95.7 \\
\hline 2 & Emete & 864 & 6 & 144 & 10 & 14 & 12 & 85.7 \\
\hline 3 & Lobia & 1203 & 5 & 241 & 10 & 24 & 21 & 87.5 \\
\hline \multirow[t]{2}{*}{4} & Azama & 1306 & 6 & 218 & 10 & 22 & 20 & 90.9 \\
\hline & Total & 4952 & 6 (average) & 828 & - & 83 & 75 & 90.4 \\
\hline
\end{tabular}


shows the four (4) major communities that were randomly selected for questionnaire distribution and analysis. These include; Obololi, Emete, Lobia and Azama communities. Results in Table 3 and Table 7 were obtained from these respondents.

\subsection{Techniques for Data Analysis}

In an attempt to satisfy the above stated objectives, solve the research problems and test the hypothesis of the study, the data collected were presented in tables and analyzed using, simple averages, percentages and frequencies.

Also the statistical technique used in testing the hypotheses of the research is the Analysis of variance (ANOVA). The ANOVA statistical model is useful in the determination of statistical differences between two or among more variables. The "F-Value" indicates the ratio of two mean squares, when the F-value is large and the significance level is small (typically smaller than 0.05 or 0.01 ) the null hypothesis can be rejected in order words, a small significance level indicates that the results probably are not due to random chance. Also the "Sig value" shows the conditional probability that a relationship as strong as the one observed in the data would be present, if the null hypothesis were true. It is often called the P-value. Typically a value of less than 0.05 is considered significant. "The Sum of squares" highlights the sum of the squared deviations about some quality, while "Df" shows the value associated with a test statistic that is used in determine the observed significance level. From the "Mean square", it is possible to know the sum of square divided by the degrees of freedom.

\section{Findings}

The findings of the study are presented below. Plates 1-4 show different scenarios of flooding in the study area.

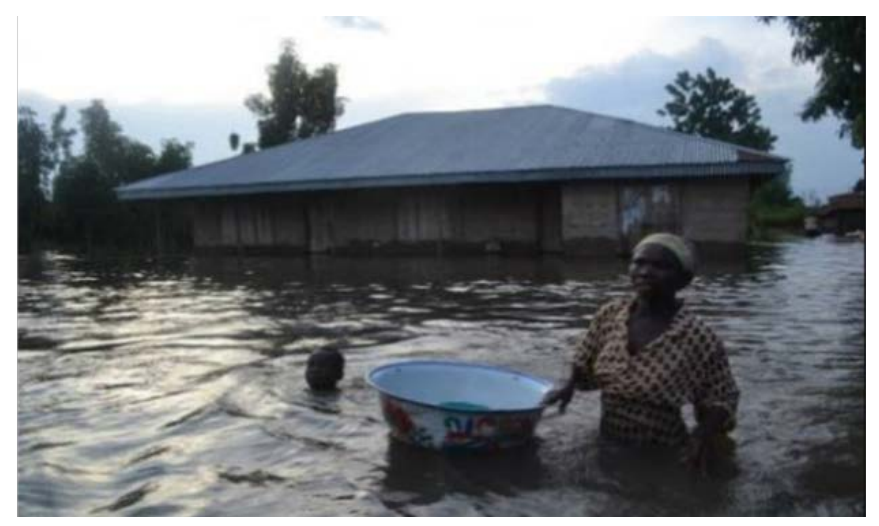

Plate 1. A Half-submerged residential building in the study area as a result of flood.

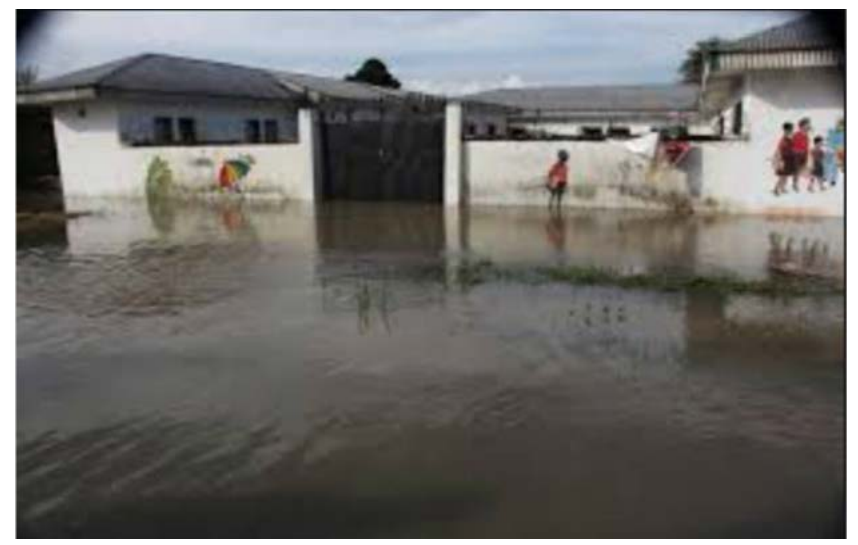

Plate 2. A school affected by flooding in Obololi community, Bayelsa state. 


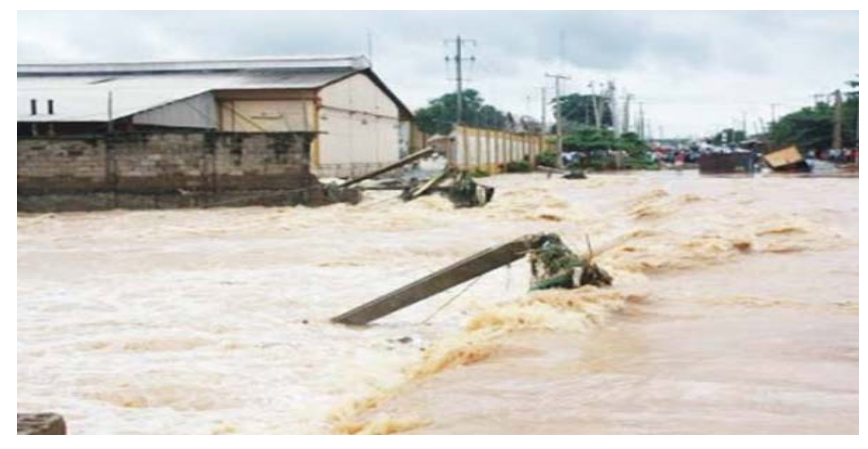

Plate 3. A flooded street in the study area.

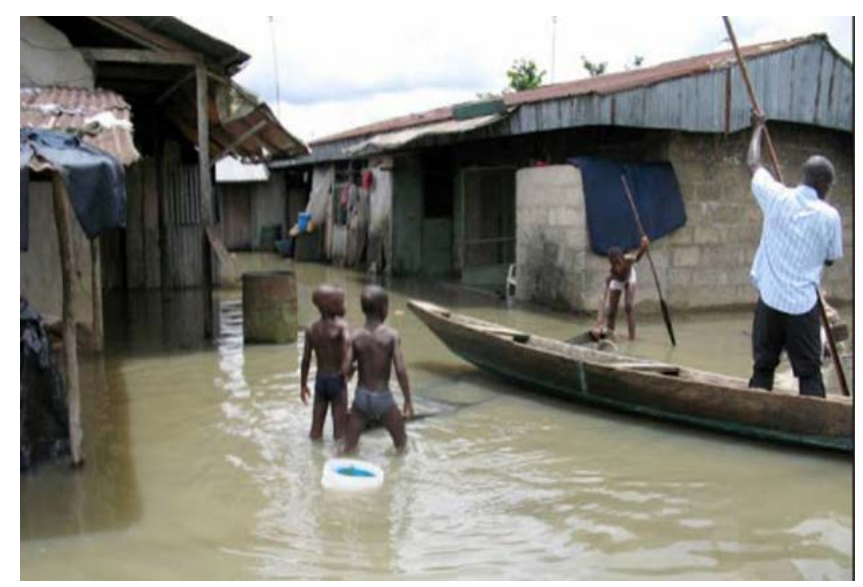

Plate 4. Azama community, Bayelsa state during flooding.

\section{Causes of Flood in the Study Area}

Table 3 presents data on the causes of flood in the sampled area. The table shows that 29 respondents (38.67\%) indicated that all the factors (All of the above) were responsible for flooding in the study area. The least observation was made by 1 respondent (1.33\%) which suggested that other factors not listed are the major causes of flooding in the study area. These include the cementing/concreting of urban areas, resulting in reduced infiltration levels. Figure 1 graphically present data in Table 3

Data were collected on earnings from customers' patronage of women and men engaged in trading activities in open and locked-up shops in Obololi, Emete, Lobia and Azama communities. Table 4: presents the results of the analysis of variance (ANOVA) aimed at testing hypothesis 1. Table 4 shows an F-value of 3.8773939 and P-value of 2.4944. Since the P-value is higher than 0.05, then the differences in the personal income by women and men engaged in marketing activities on flood and non-flood days in the study area is not statistically significant. Thus we accept null hypothesis, which state that "There is no statistically significant difference in the income earned by men and women traders from marketing activities on flood days and non-flood days in Southern Ijaw Local Government Area, Bayelsa State". The ownership of shops in easily flooded areas appears not to have resulted in significant difference in the earnings within the flood and non-flood days for men and women in the study area.

ANOVA results in Table 5: which considers differences in the income among women from transactions during flood and non-flood days is meant to test null hypothesis $\left(\mathrm{H}_{0}\right)$ II (There is no statistically significant difference in the income earned by women traders from marketing activities on flood and non-flood days in Southern Ijaw Local Government Area, Bayelsa State). Table 5 shows an F-value of 2.534902 and P-value of 0.030059. Since the P-value is less than 0.05 level of significance, then there is a statistically significant difference in the income by market women on flood and non-flood days. Thus null hypothesis II is rejected and the alternative hypothesis which states that there is a statistically significant difference is accepted.

Table 6 shows a progressive decrease in total sales from day one of flood to day three from N676,008 
Table 3. Responses on the causes of flood in the study area.

\begin{tabular}{cccc}
\hline S/N & Causes of flood & Frequency & \% \\
\hline 1 & Excessive rainfall & 10 & 13.33 \\
2 & Blockage of drainage channel & 11 & 14.67 \\
3 & Construction of residences on floodable areas & 3 & 4.00 \\
4 & Lack of adequate drainage system & 8 & 10.67 \\
5 & Increase in sea level & 7 & 9.33 \\
7 & All of the above & 29 & 38.67 \\
& Others (specify) & 1 & 1.33 \\
\hline
\end{tabular}

Table 4. Result of analysis of variance (ANOVA) on data collected on personal income by male and female traders on flood and non-flood days in the study area.

\begin{tabular}{|c|c|c|c|c|c|c|}
\hline ANOVA & & & & & & \\
\hline \multicolumn{7}{|l|}{ Summary } \\
\hline Groups & Count & Sum & Average & Variance & & \\
\hline Day 1 men flood & 33 & 676,008 & $20,485.09091$ & $490,177,139.5$ & & \\
\hline Day 2 men flood & 33 & 446,116 & $13,518.66667$ & $304,571,888.4$ & & \\
\hline Day 3 men flood & 33 & 294,085 & 8911.666667 & $144,368,552.5$ & & \\
\hline Day 1 no flood men & 33 & 556,467 & $16,862.63636$ & $447,516,285.7$ & & \\
\hline Day 2 no flood men & 33 & 750,201 & $22,733.36364$ & $564,632,626.4$ & & \\
\hline Day 3 no flood men & 33 & 718,404 & $21,769.81818$ & $245,302,790$ & & \\
\hline Day 1 women flood day & 33 & 454,739 & $13,779.9697$ & $279,667,857.2$ & & \\
\hline Day 2 women flood day & 33 & 229,380 & 6950.909091 & $70,710,713.65$ & & \\
\hline Day 3 women flood day & 33 & 158,859 & 4813.909091 & $14,714,488.96$ & & \\
\hline Day 1 women no flood & 33 & 293,148 & 8883.272727 & $61,229,525.14$ & & \\
\hline Day 2 women no flood & 33 & 314,034 & 9516.181818 & $27,835,708.65$ & & \\
\hline Day 3 women no flood & 33 & 552,114 & $16,730.72727$ & $1,064,112,895$ & & \\
\hline \multicolumn{7}{|l|}{ ANOVA } \\
\hline Source of Variation & SS & $D f$ & MS & $\boldsymbol{F}$ & P-value & F crit \\
\hline Between Groups & $13,203,574,800$ & 11 & $1,200,324,982$ & 3.8773939 & $2.4944 \mathrm{E}-05$ & 1.813615 \\
\hline Within Groups & $1.18875 E+11$ & 384 & $309,570,039.2$ & & & \\
\hline Total & $1.32078 E+11$ & 395 & & & & \\
\hline
\end{tabular}

(47.73\%) to N292,085 (20.77\%) for male traders during flood days. The same observation of increase from day one to day three is true for marketing sales by women during flood days from N454,739 (53.94\%) to N158,859 (18.84\%). The reverse is observed for both men and women on non-flood days, where sales tend to surge from the first days of study towards the last days. Notably the data for non-flood days were collected a day after flood had receded and rain had stopped.

It appears that trading tends to build up gradually, and appears to peak as traders and invariably buyers gain confidence, that the markets will be more operational. Generally incomes earned by women traders were noticed to be often lower than those of men traders during flood days and non-flood days. The nature of goods sold, quantities and the differences in their prices may have caused this difference. For instance a male or female 
Table 5. Result of analysis of variance (ANOVA) on data collected on personal income earned by female traders on flood and non-flood days in the study area.

\begin{tabular}{|c|c|c|c|c|c|c|}
\hline ANOVA & & & & & & \\
\hline \multicolumn{7}{|l|}{ SUMMARY } \\
\hline Groups & Count & Sum & Average & Variance & & \\
\hline Day 1 women flood day & 33 & 454,739 & $13,779.97$ & $2.8 \mathrm{E}+08$ & & \\
\hline Day 2 women flood day & 33 & 229,380 & 6950.909 & $70,710,714$ & & \\
\hline Day 3 women flood day & 33 & 158,859 & 4813.909 & $14,714,489$ & & \\
\hline Day 1 women no flood & 33 & 293,148 & 8883.273 & $61,229,525$ & & \\
\hline Day 2 women no flood & 33 & 314,034 & 9516.182 & $27,835,709$ & & \\
\hline Day 3 women no flood & 33 & 552,114 & 16730.73 & $1.06 \mathrm{E}+09$ & & \\
\hline \multicolumn{7}{|l|}{ ANOVA } \\
\hline Source of Variation & SS & $D f$ & MS & $\boldsymbol{F}$ & P-value & F crit \\
\hline Between Groups & $3.21 \mathrm{E}+09$ & 5 & $6.41 \mathrm{E}+08$ & 2.534902 & 0.030069 & 2.261137581 \\
\hline Within Groups & $4.86 \mathrm{E}+10$ & 192 & $2.53 \mathrm{E}+08$ & & & \\
\hline Total & $5.18 \mathrm{E}+10$ & 197 & & & & \\
\hline
\end{tabular}

Table 6. Pattern of income from patronage by customers during flood and non-flood days.

\begin{tabular}{ccccccccc}
\hline $\begin{array}{c}\text { Flood } \\
\text { Days }\end{array}$ & $\begin{array}{c}\text { Men } \\
\text { (Flood } \\
\text { Days) }\end{array}$ & $\%$ & $\begin{array}{c}\text { Men } \\
\text { (Non-Flood } \\
\text { Days) }\end{array}$ & $\%$ & $\begin{array}{c}\text { Women } \\
\text { (Flood } \\
\text { Days) }\end{array}$ & \% & $\begin{array}{c}\text { Women } \\
\text { (Non-Flood } \\
\text { Days_ }\end{array}$ & $\%$ \\
\hline $\mathbf{1}$ & $\mathbf{N 6 7 6 , 0 0 8}$ & $47.73 \%$ & $\mathbf{5 5 6 , 4 6 7}$ & $27.48 \%$ & $\mathbf{4 5 4 , 7 3 9}$ & $53.94 \%$ & $\mathbf{2 9 3 , 1 4 8}$ & $25.29 \%$ \\
$\mathbf{2}$ & $\mathbf{N 4 4 6 , 1 1 6}$ & $31.50 \%$ & $\mathbf{7 5 0 , 2 0 1}$ & $37.05 \%$ & $\mathbf{2 2 9 , 3 8 0}$ & $27.21 \%$ & $\mathbf{3 1 4 , 0 3 4}$ & $27.09 \%$ \\
$\mathbf{3}$ & $\mathbf{N 2 9 4 , 0 8 5}$ & $20.77 \%$ & $\mathbf{7 1 8 , 4 0 4}$ & $35.48 \%$ & $\mathbf{1 5 8 , 8 5 9}$ & $18.84 \%$ & $\mathbf{5 5 2 , 1 1 4}$ & $47.62 \%$ \\
& $\mathrm{~N} 1,416,209$ & $100.00 \%$ & $\mathbf{2 , 0 2 5 , 0 7 2}$ & $100.00 \%$ & 842,978 & $100.00 \%$ & $1,159,296$ & $100.00 \%$ \\
\hline
\end{tabular}

trader selling a particular product in retail may not make as much income as a male or female trader selling the same product in wholesale transactions, although depending on the frequency of transactions too.

Table 6 also shows that women are more vulnerable, since they earn less compared to the male traders during rainy seasons. Oral interviews however revealed that sometimes a male trader could have two or more shops trading on the same or different items. He most likely will manage the bigger shop(s) while his wife and/or an apprentice manage the other(s). The sales profits are for the same household. In some cases the businesses do not belong directly or wholly to women traders who are spouses of the real owners. It was observed also that some "women traders" encountered in the study area, are mere sales persons who are paid monthly or on commission.

Table 7 presents data on the possible strategies for controlling flood incidence in the study area. The table reveals that 33 (44\%) respondents in the sampled area agreed that all the mentioned factors as designated by "All of the above" is the most important factor. Also $12(16 \%)$ respondents agreed that the most important factor is the need for the "Construction of more drainage channels", while 5 (6.7\%) respondents pointed out that there is a need for the "Avoidance of construction on flood plains". This implies that all the options in Table 7 are needed in order to control flood incidence in the sampled areas.

\section{Recommendations}

It is therefore appropriate in this chapter to highlight some policy consideration which, if implemented could play an important role in flood risk management. The following policy consideration is recommended:

1) Government and key stakeholders should encourage communities to relocate permanently to higher 
Table 7. Control measures on re-current flooding in study area.

\begin{tabular}{cccc}
\hline S/N & Control measures & Frequency & \% \\
\hline 1 & Construction of more Drainage & 12 & 16 \\
2 & Early monitoring and warning & 11 & 14.7 \\
3 & Widening of existing drainage channels & 8 & 10.6 \\
4 & Enactment of policies that restrict dumping of waste in drainage channels & 6 & 8.0 \\
5 & Avoidance of construction on flood plains & 5 & 6.7 \\
6 & All of the above & 33 & $\mathbf{4 5 . 0}$ \\
& Total & $\mathbf{7 5}$ & $\mathbf{1 0 0}$ \\
\hline
\end{tabular}

Source: Fieldwork, 2015.

grounds and non-floodable areas. The relocation should go with the provision of all necessary socio-infrastructural amenities such as schools, hospitals, infrastructure, pipe-borne water and agriculture inputs for a period not lesser than three (3) years to enable the household members to settle down. Efforts should also be made to introduce alternative livelihood strategies in the new areas of settlement.

2) Government and private investors should provide conducive buildings and areas for business operations, and avoid flood prone areas, while giving better consideration to the female gender.

3) The relevant authorities should delineate both the non-flood areas and flood areas. These should be reflected in widely distributed documents.

4) Construction of dams should be considered to trap excess water. This could be used for irrigation in other areas where water is scarce and also for hydroelectricity. However careless release of dam water could be disastrous.

5) Community based flood-early-warning-systems should be developed.

6) Community initiated mitigation measures should be promoted, so as to build community resilience. Indigenous knowledge should also be identifies and applied in managing flood events

7) Although the consequences of flood may be assumed to be limited to reduced total household income, the implication of reduced household income on family food security and nutrition, as well as the implications of rainy days and resultant cold related ailments caused by chilly weather on human health, exposure to germs saturated flood water, and resultant mosquito breeding in stagnant water, needs to be adequately researched and appropriate management strategies adopted. These are of public health importance.

8) Revolving, low collateral requiring loans should be made available to women to begin or enlarge their trading businesses by governments at different levels for woman development purposes.

\section{Conclusions}

This study examined the socio-economic implication of flooding on the incomes of female and male traders in southern Ijaw Local Government Area, Bayelsa State. The objective was focused on knowing the level to which flooding affected women development ranging from their personal income to the pattern of patronage and was aimed at establishing the more vulnerable gender group in the study area. Flooding is generally a temporary condition of partial or complete inundation of normally dry area of land, due to over flow of inland or tidal waters, or from unusual and rapid accumulation or run-off [4]. The fact that [31] has pointed out that Bayelsa State was the state most affected in the Niger Delta region during the 2011 flood event, significantly justify research efforts aimed at managing flood in the study area.

The study reveals that although there is no statistically significant difference in the personal income earned by business men and women on flood days and non-flood days, female traders are adversely affected by flooding in terms of their livelihood patterns. Women traders were shown to be earning lesser income during flood and nonflood days than men. Surprisingly, there is a statistical significant difference in the personal income earned among business women on flood and non-flood days.

Candidly, it was expected before the study that this would be the other way round. This finding could be because there is a very wide divide in the level of trading activities of women traders and the investments involved. Respondents during oral interviews, unanimously pointed out that a woman trader, with her own business, could 
be engaged in the sales of minor products, such as China manufactured Padlocks and Ball pens in a tiny locked-up shop sandwiched between other shops in a respectable trading neighborhood. It's difficult to imagine how such a female trader is able to afford the monthly or annual shop rents, given the paltry profits she must have been making. She may daily collect her wares on loan, sell and return the costs of the goods, minus her profits to a wholesaler. However, another woman may be a textile goods trader that visits Yenagoa regularly, and sells at wholesale prices.

Oral interviews further revealed that many of the prosperous women traders belonging to the latter group had businesses buoyed by investment funding by their male spouses. Sometimes it's also difficult to identify a dichotomy in the income flow and savings between a so called "prosperous" female trader's business stocks and those of the husband's business. All such trading shops are most likely extensions of the same expanding business, sometimes with the same or different registered names. Thus there is observed disparity in the earnings of female traders with own business and usually those with funds from spouse's business. Marriage and not bank loans tend to be a major cushion of poverty amongst women.

Painfully, the general situation of low income and independent women traders in the study area is extremely pathetic. Large proportions are hawkers, and are major household income earners, who in their day to day lives are grossly marginalized by poverty, from achieving their well-deserved dreams of good education for their children, social well-being and comfort. A situation of total and draconian government clamp-down like that, which is presently being enforced in Lagos state [33], will be more crippling, not only in Bayelsa state, but in all Niger Delta areas, given the already existing dehumanizing living conditions and induced environmental degradation. Taking away the sole means of livelihood, irrespective of apparently amplified necessity (for transport management and school attendance) may result in induced crime increase, prostitution, school dropout trends, suicides, psychological breakdowns, malnutrition and child neglect, vandalism and sabotage of community facilities and infrastructure.

Bayelsa state is a region which is prone to flooding due to high rainfall and long rainy days. This poses considerable problems for socio-economic activities, human settlements and land-use. Almost every part of the area is under water at one time of the year or another. The research recommends that government should provide non-floodable and conducive areas for building business premises with gender consideration.

\section{References}

[1] Ward, R.C. (1974) Principles of Hydrology. McGraw-Hill International Publishing Company, London.

[2] Chen, Y. (2004) Living with Flood Victim’s Perception in Beijiang, Guangohons China.

[3] European Commission (EC) (2007) Directive 2007/60/EC of the European Parliament and of the Council of 23 October, 2007 on the Assessment and Management of Flood Risks. Official Journal of the European Union, L288, 27-34. http://eurlex.europa.eu/LexUriServ/LexUriServ.do?uri=OJ:L:2007:288:0027:0034:EN:PDF

[4] Jeb, D.N. and Aggarwal, S.P. (2008) Flood Inundation Hazard Modeling of the River Kaduna Using Remote Sensing and Geographic Information Systems. Journal of Applied Sciences Research, 4, 1822-1833.

[5] Brown, J.D. and Damery, S.L. (2002) Managing Flood Risk in UK: Towards an Integration of Social and Technical Perspectives. Transactions of the Institute of British Geographers, 27, 412-426. http://dx.doi.org/10.1111/1475-5661.00063

[6] Adeoye, N.O., Ayanlade, A. and Babatimehin, O. (2009) Climate Change and Menace of Floods in Nigerian Cities: Socio-Economic Implications. Advances in Natural and Applied Sciences, 3, 369-377.

[7] Balabanova, S. and Vasiler, V. (2010) Creation of Flood Hazard Maps. BALWOIS, Onrid.

[8] Kwak, Y. and Kondoh, A. (2008) A Study on the Extraction of Multi-Factor Influencing Floods from Remote Sensing Images and GIS Data: A Case Study in Nackdong Basin, South Korea. Centre for Remote Sensing, Chiba.

[9] Paeth, H., Fink, A.H., Pohle, S., Keis, F., Machel, H. and Samimi, C. (2010) Meteorological Characteristics and Potential Causes of the 2007 Flood in Sub-Saharan Africa. International Journal of Climatology, 31, 1908-1926. http://dx.doi.org/10.1002/joc.2199

[10] Winser, B. (1979) Flood Prevention and Mitigation in the People’s Republic of Mozambique, Disaster's. Disaster, 3, 293-306. http://dx.doi.org/10.1111/j.1467-7717.1979.tb00155.x

[11] Anwar, H.M. (2008) The Impact of Recurring Natural Disasters on Chronic Poverty. Societies without Borders, 3, 285-301. http://dx.doi.org/10.1163/187219108X300082

[12] UN (2004) International Strategy for Disaster Reduction (ISDR) Summit. United Nations, Geneva. 
[13] Jeyaseelan, A.T. (2004) Droughts and Floods Assessment and Monitoring Using Remote Sensing and GIS. Proceedings of Satellite Remote Sensing and GIS Applications in Agricultural Meteorology, 291- 313.

[14] Etuonoobe, A.K. (2011) The Divesting Effect of Flooding in Nigeria. AnGene Surveys \& Consultants, FIG Working Week 2011, Bridging the Gap between Cultures, Marrakech, Morocco. http://www.fig.net/resources/proceedings/fig proceedings/fig2011/papers/ts06j/ts06j_etuonovbe 5002.pdf

[15] Nott, J. (2006) Extreme Evening: A physical reconstruction and Risk Assessment. Cambridge University Press, New York. http://dx.doi.org/10.1017/CBO9780511606625

[16] Mwape, V.P. (2009) An Impact of Floods on the Socio-Economic Livelihoods of People: A Case Study of Sikaunzwe Community in Kazungula District of Zambia. A Mini Dissertation for the Award of Masters Degree in Disaster Risk Management, Disaster Risk Management Training and Education Centre for Africa (DIMTEC), Faculty of Natural and Agricultural Sciences, University of the Free State, Bloemfontein.

[17] Living with Risk (2002) A Global Review of Disaster Reduction Initiative. Geneva.

[18] Grunfet, E. (1995) Hydro Meteorological, Impacts and Management of Extreme Floods. Workshop on Long-Term Social and Economic Impacts of Extreme Floods, University of Colorado, November 1995.

[19] United Nations Office for Disaster Risk Reduction (2005) Know Risk, United Nations Office for Disaster Risk Reduction (UNISDR)/(Tudor Rose Publishers), United Nations, Geneva. In: Mwale, Y.P. (2009) An Impact of Floods on the Socio-Economic Livelihood of People: A Case Study of Sikaunzue Community in Kazungula District of Zambia. A Mini Dissertation for the Award of Masters Degree in Disaster Risk Management. University of the Free States, Bloemfontein.

[20] Lindsell, K.M. and Prater, S.C. (2003) Abstract on “Assessing Community Impacts of National Disasters”: 176-178 (Electronic). National Hazard Review, 4, 176-185.

[21] Ariyanbandu, M.M. and Wackramasinghe, W.M. (2005) Gender Dimension in Disaster Management: A Guide for South Asia. ITDGPractical Action South Asia Publication, Srilanka.

[22] Hansson, K., Danielson, M. and Ekenberg, L. (2008) A Framework for Evaluation of Flood Management Strategies. Journal of Environmental Management, 86, 465-480.

[23] Rashid, F.S. (2000) The Urban Poor in Dhaka City: Their Struggles and Coping Strategies during the Floods of 1998. Disasters, 24, 240-253. http://dx.doi.org/10.1111/1467-7717.00145

[24] Parker, J.D. (2000) Floods. Tangler and Francis, National Academy Press, Asian Disaster Preparedness Centre, Thailand.

[25] Federal Ministry of Environment (2009) Establishment of Early Warning System in Nigeria. The Federal Ministry of Environment, Department of Erosion Flood and Coastal Zone Management, in Collaboration with the United Nation Development Programme, Final Report by AI Jireh Associates, Abuja.

[26] APFN (2008) Urban Flood Risk Management WMO-Technical Document No. 11. Flood Management Tools Series (Associated) Programme on Flood Management, World Meteorological Organization and Global Water Partnership.

[27] Kadafa, A.A. (2012) Oil Exploration and Spillage in the Niger Delta of Nigeria. Civil and Environmental Research, 2, 38-51.

[28] African Research Bulletin (ARB) (2010) Policy and Practice, Economic Trends, Benin. Counting the Cost of Floods, Africa Research Bulletin: Economic, Financial and Technical Series, 47, 18902-18903.

[29] Abbas, I.I. (2008) Use of Satellite Remote Sensing and Geographic Information Systems to Monitor Land Degradation along Ondo Coastal Zone (Nigeria). BACWOLS, Ohird.

[30] Ologunorisa, T.E. and Abawua, M.J. (2005) Flood Risk Assessment: A Review. Journal of Applied Sciences and Environmental Management, 9, 57-63.

[31] Odubo, T.R (2014) The Socio-Cultural Effects of Flooding in Bayelsa State: A Case Study of Southern Ijaw Local Government Area, Mediterranean Journal of Social Sciences, 5, 1443-1450.

http://www.mcser.org/journal/index.php/mjss/article/view/5228/5045 http://dx.doi.org/10.5901/mjss.2014.v5n27p1443

[32] NPC Census (2015) Population Census Report. National Population Commission, Abuja.

[33] Lagos State Government (2016) Lagos Goes Tough on Street Trading, Hawking. http://www.lagosstate.gov.ng/2016/07/01/lagos-goes-tough-on-street-trading-hawking 


\section{Submit or recommend next manuscript to SCIRP and we will provide best service for you:}

Accepting pre-submission inquiries through Email, Facebook, LinkedIn, Twitter, etc.

A wide selection of journals (inclusive of 9 subjects, more than 200 journals)

Providing 24-hour high-quality service

User-friendly online submission system

Fair and swift peer-review system

Efficient typesetting and proofreading procedure

Display of the result of downloads and visits, as well as the number of cited articles

Maximum dissemination of your research work

Submit your manuscript at: http://papersubmission.scirp.org/ 